ISSN 0258-7122 (Print), 2408-8293 (Online)

Bangladesh J. Agril. Res. 42(3): 571-588, September 2017

\title{
CHARACTER ASSOCIATION AND PATH CO-EFFICIENT ANALYSIS IN WHEAT (Triticum aestivum $L$.)
}

\author{
M. F. AMIN ${ }^{1}$, M. HASAN ${ }^{2}$, N. C. D. BARMA ${ }^{3}$, M. A. RAHMAN ${ }^{4}$ \\ AND M. M. RAHMAN ${ }^{5}$
}

\begin{abstract}
The experiment was carried out with 50 wheat lines to study their mean, range, cv (\%), correlation co- efficient, and path co- efficient considering 14 different morphological characters at the experimental field of Regional Wheat Research Centre (RWRC), Bangladesh Agricultural Research Institute (BARI), Gazipur during December 2010 to April 2011. Significant variation was observed among the genotypes for all characters studied. In general, genotypic correlations were higher than the phenotypic correlations. It indicates that there was an inherent association among them which was adversely influenced by the environment. The correlation coefficients showed that, seed yield was negatively and significantly correlated with days to heading (DTH), plant height (PHT), days to anthesis (DTA), days to physiological maturity (DPM), and canopy temperature at anthesis stage (CTanth.) but only negatively correlated with canopy temperature at vegetative stage (CTveg.), canopy temperature at grain filling stage (CTgf.), spikelets per spike both genotypically and phenotypically and grain per spike showed genotypically negative correlation. Path analysis showed that plant height (PHT), days to physiological maturity (DPM), canopy temperature at grain filling stage (CTgf.), and thousand grain weight (TGW) influenced seed yield directly in positive direction but days to heading (DTH), days to anthesis (DTA), grain filling duration (GFD), grain filling rate (GFR), Chlorophyll content at anthesis stage $\left(\mathrm{CHL}_{\mathrm{A}}\right)$, canopy temperature at vegetative stage (CTveg.), canopy temperature at anthesis stage (CTanth.), spikelets per spike, and grains per spike had negative direct effect on seed yield. Considering analytical findings of correlation co-efficient, path co-efficient analysis and field performance, the genotypes G 3, G 10, G 11, G 12, G13, G 21, G 29, G 35, G $38, \mathrm{G} 40, \mathrm{G} 46$ and $\mathrm{G} 48$ were found suitable for future breeding programme.
\end{abstract}

Keywords: Character association, Path co-efficient analysis, Wheat, genotypes.

\section{Introduction}

Wheat in Bangladesh has been established as second most important cereal crop next to rice. To meet the increasing demand of wheat in Bangladesh and to decrease import, local production needs to be increased faster. Wheat Research

${ }^{1}$ Scientific Officer, ${ }^{5}$ Senior Scientific Officer, ${ }^{4}$ Principle Scientific Officer, and ${ }^{3}$ Chief Scientific Officer, Regional Wheat Research Centre (RWRC), Bangladesh Agricultural Research Institute (BARI), Gazipur, ${ }^{2}$ Associate Professor, Department of Genetics and Plant Breeding, Bangabandhu Sheikh Mujibur Rahman Agricultural University (BSMRAU), Salna, Gazipur, Bangladesh 
Centre (WRC) of Bangladesh Agricultural Research Institute (BARI) now has a wide range of spring wheat germplasm collection from different sources. Most of these have been collected from International Maize and Wheat Improvement Centre (CIMMYT), Mexico and few from Nepal, India, Pakistan, Australia etc. Determination of correlation co-efficient between the characters has a considerable importance in selecting breeding materials. The path co-efficient analysis gives more specific information on the direct and indirect influence of each of the component characters upon seed yield (Behl et al., 1992). Selection of grain yield becomes difficult unless the association among the yield contributing characters are known. So estimation of correlation helps to identify the relative contribution of component characters towards yield (Panse, 1957). As yield is the main objective to a breeder, it is important to know the relationship among various characters that have direct and indirect effect on yield. Yield components influence the ultimate yield of a crop both directly and indirectly (Turkey, 1954). Path analysis specifies the causes and effect relationship and measures the relative importance of each variable (Wright, 1959). Therefore, correlation in combination with path co-efficient analysis will be an important tool to find out the association between direct and indirect effects and quantify the direct and indirect influence of one character upon another (Dewey and Lu, 1959). The correlation co-efficient between yield and yield contributing characters usually show a complex chain of interacting relationship. Path co-efficient estimates the direct and indirect effects of different yield contributing characters towards the yield through correlation co-efficient analysis and visualize the relationship in more meaningful way. Therefore, the present study was undertaken to find out and establish suitable selection criteria for higher yield through study of relationship between yield and yield components in spring wheat.

\section{Materials and Method}

Fifty wheat genotypes were grown in a randomized complete block design with three replications at the experimental field of Bangladesh Agricultural Research Institute, Gazipur during first week of December 2010 to first week of April 2011. The experimental site was at $23.46^{\circ} \mathrm{N}$ latitude and $90.23^{\circ} \mathrm{E}$ longitude with an elevation of 8 meter from sea level. The experimental field was prepared thoroughly by ploughing with tractor followed by harrowing and removing the stubbles. The crop was fertilized with NPKS and B @ 100, 28, 40, 20 and $2.5 \mathrm{~kg}$ $\mathrm{ha}^{-1}$ respectively to ensure proper growth and development. The elements $\mathrm{N}, \mathrm{P}$, $\mathrm{K}, \mathrm{S}$ and B were applied in the form of Urea, Triple Super Phosphate,

Muriat of Potash, Gypsum and Boric acid respectively. Two-third of urea and the entire quantity of other fertilizers were applied at final land preparation along with Furadon 3G @ $8 \mathrm{~kg} \mathrm{ha}^{-1}$ (Anon. 2011). The rest one-third urea was topdressed at crown root initiation stage (17-21 days after sowing) following first irrigation. Data were collected on days to heading (DTH), days to anthesis (DTA), days to maturity (DTM), grain filling duration (GFD)[(days], grain filling 
rate (GFR) $\left[\mathrm{g} \mathrm{m}^{-2} \mathrm{~d}^{-1}\right]$, plant height (PHT) in $\mathrm{cm}$, chlorophyll content at anthesis $\left(\mathrm{CHL}_{\mathrm{A}}\right)$ in SPAD unit, canopy temperature $\left({ }^{\circ} \mathrm{C}\right)$ at vegetative $\left(\mathrm{CT}_{\text {veg. }}\right)$, anthesis $\left(\mathrm{CT}_{\text {anth. }}\right)$ and grain filling $\left(\mathrm{CT}_{\text {gf. }}\right)$ stage, spikelets spike ${ }^{-1}$ (no.), grains spike ${ }^{-1}$ (no.), thousand grain weight (TGW) $[\mathrm{g}]$, and grain yield $\mathrm{m}^{-2}(\mathrm{~g})$. Grain yield $\mathrm{m}^{-2}$ of each genotype was converted into grain yield per hectare $(\mathrm{Kg} / \mathrm{ha})$. The data were analyzed for different components. Phenotypic and genotypic variances were estimated by the formula used by Johnson et al. (1955). Phenotypic and genotypic co-efficient of variation were calculated by the formula of Burton (1952). Simple correlation co-efficient was obtained using the formula suggested by Clarke (1973); Singh and Chaudhary (1985). Genotypic and phenotypic correlation co-efficient were calculated following Miller et al. (1958). Path coefficient analysis was done following the method outlined by Dewey and Lu (1959).

\section{Results and discussion}

The mean, range, and CV of seed yield and yield contributing characters of 50 genotypes of spring wheat are presented in Table 1. Variations were observed among the lines for all the characters studied. The average days to heading (DTH) across genotypes was 72.77 days and ranged from 61 to 79 days (Table 2). The minimum DTH was observed in genotype G 21 (61.67 days) and the maximum (79 days) in genotype G 27 (Table 2). Days to anthesis (DTA) ranged from 65 to 84 (Table 1). Shorter vegetative period was observed in the genotype G 21 (65.33) and the longer (84.33) in the genotype G 27 (Table 2). Days to physiological maturity (DPM) ranged from 98 to 111 (Table 1). The lowest days to physiological maturity was observed in the genotype G 21 (98.33) and the highest (111.33) in the genotype G 27 (Table 2). Grain filling duration (GFD) ranged from 23 to 34 days (Table 1). Shorter GFD was recorded in genotype G 29 (23.33 days) and the longer one ( 34.00 days) in genotype $G 44$ (Table 1 ). The average Grain filling rate (GFR) across genotypes was $14.43 \mathrm{~g}^{-2} \mathrm{~d}^{-1} \mathrm{~m}^{-2}$ and ranged from 10.07 to 18.98 (Table 1). Minimum GFR was observed in genotype G $3\left(10.07 \mathrm{~g} \mathrm{~g}^{-2} \mathrm{~d}^{-1} \mathrm{~m}^{-2}\right)$ and the maximum $\left(18.98 \mathrm{~g}^{-2} \mathrm{~d}^{-1} \mathrm{~m}^{-2}\right)$ in genotype $\mathrm{G} 40$ (Table 2). Plant height (PHT) ranged from 80 to $98 \mathrm{~cm}$ (Table 1). The minimum plant height was observed in the genotype $G 3(80.33 \mathrm{~cm})$ and the maximum $(97.67 \mathrm{~cm})$ in the genotype G 4 and G16 (Table 2). The average Chlorophyll content at anthesis stage $\left(\mathrm{CHL}_{\mathrm{A}}\right)$ across genotypes was 49.51 SPAD unit for all genotypes and ranged from 43.50 to 54.53 (Table 1). The highest chlorophyll content (54.50 SPAD unit) was recorded in genotype G 45 while the lowest chlorophyll content (43.50 SPAD unit) was recorded in G 2 (Table 2). The canopy temperature measured by infrared thermometer has been used to evaluate genotypes for their ability to keep their canopy cool with less impaired assimilation processes as suggested by Reynolds et al., (1994). Canopy temperature at vegetative stage $\left(\mathrm{CT}_{\text {veg. }}\right.$ ) ranged from 19.90 to $22.50{ }^{\circ} \mathrm{C}$ (Table 1). Minimum average canopy temperature at vegetative stage was recorded in the genotype $\mathrm{G} 46\left(19.90{ }^{\circ} \mathrm{C}\right)$ and the maximum $\left(22.50{ }^{\circ} \mathrm{C}\right)$ was in the genotype $\mathrm{G} 7$ 
(Table 1). Canopy temperature at anthesis stage $\left(\mathrm{CT}_{\text {anth.) }}\right.$ ranged from 21.10 to $23.50{ }^{\circ} \mathrm{C}$ (Table 1). Minimum average canopy temperature was recorded in the genotype $\mathrm{G} 39\left(21.10^{\circ} \mathrm{C}\right)$ and the maximum $\left(23.50{ }^{\circ} \mathrm{C}\right)$ was in the genotype $\mathrm{G} 15$ (Table 2). Canopy temperature at grain filling stage $\left(\mathrm{CT}_{\text {gf. }}\right)$ ranged from 21.50 to $24.90{ }^{\circ} \mathrm{C}$ (Table 1). The minimum average canopy temperature was recorded in the genotype $\mathrm{G} 44\left(21.50{ }^{\circ} \mathrm{C}\right)$ and the maximum $\left(24.90{ }^{\circ} \mathrm{C}\right)$ was in the genotype G 15 (Table 2). Spikelets spike ${ }^{-1}$ ranged from 13.90 to 18.40 (Table 1). The minimum spikelets spike ${ }^{-1}$ produced by the genotype G 3 (13.90) and the maximum (18.40) by genotype $\mathrm{G} 38$ (Table 2). The average Grain spike ${ }^{-1}$ across genotypes was 50.74 and ranged from 40.70 to 57.90 (Table 1). Genotype G 49 produced minimum grains spike ${ }^{-1}(40.70)$ while $\mathrm{G} 35$ produced the maximum (57.90) grains (Table 2). Thousand grain weight (TGW) ranged from 30.50 to $45.90 \mathrm{~g}$ (Table 1). The lowest 1000-grain weight was recorded in the genotype $\mathrm{G}$ $4(30.50 \mathrm{~g})$ and the highest $(45.90 \mathrm{~g})$ was in genotype $\mathrm{G} 13$ (Table 2). The average Grain yield was $3810.14 \mathrm{~kg} \mathrm{ha}^{-1}$ for all genotypes and ranged from 2552 to 4998 $\mathrm{kg} \mathrm{ha}^{-1}$ (Table 1). G 41 was the lowest yielder $\left(2552.00 \mathrm{~kg} \mathrm{ha}^{-1}\right)$ while $\mathrm{G} 40$ was the highest yielder (4998.00 $\mathrm{kg} \mathrm{ha}^{-1}$ ) among the genotypes studied (Table 2). The highest co-efficient of variation $(\mathrm{CV} \%)$ was recorded in the character grain filling rate (13.94) followed by grain yield (13.68), grain filling duration (9.32), and TGW (8.86) (Table 1).Considering the plant height, days to heading, days to maturity, grain filling duration, grains per spike, spikelets per spike, thousand grain weight, seed yield and other yield contributing characters, the genotypes $\mathrm{G}$ 3, G 13, G 21, G 29, G 35, G 38, G40, and G 46 were selected for future breeding programme.

\section{Character association}

Yield is a complex character and related with several yield contributing attributes. Selection for yield would not be effective unless other yield components influence it directly or indirectly. If selection pressure is given for improvement of any character highly associated with yield it will affect other correlated traits. Thus, interrelationship among different characters with yield will help breeders to improve the desired traits through selection.

\section{Correlation co- efficient}

Genotypic $\left(r_{\mathrm{g}}\right)$ and phenotypic $\left(\mathrm{r}_{\mathrm{p}}\right)$ correlation coefficients between pairs of fourteen quantitative traits are presented in Table 3. In general, the genotypic correlation coefficient values were higher than the phenotypic values. This indicated that strong intrinsic associations were somewhat masked at phenotypic level due to environmental effects. Many investigators (Barma et al., 1990; Barma et al., 2002 and Rahman, 2009) had reported high estimates of genotypic correlation than phenotypic correlation. It revealed that inherent relationships between two traits were suppressed by the environmental influence at phenotypic level. The results are discussed character wise as follows: 
Table 1. Mean, Range, and CV (\%) of seed yield and yield contributing characters of fifty spring wheat genotypes

\begin{tabular}{l|ccccccccc}
\hline Component & MSp & $\mathrm{MS}_{G}$ & $\mathrm{MS}_{E}$ & Mean & Range & CV\% & F-value \\
\hline DTH & 41.693 & 41.088 & 0.605 & 72.77 & $61-79$ & 5.12 & $* *$ \\
DTA & 50.398 & 49.804 & 0.594 & 76.83 & $65-84$ & 5.34 & $* *$ \\
DPM & 22.278 & 21.684 & 1.372 & 103.35 & $98-111$ & 2.64 & $* *$ \\
GFD & 18.348 & 17.754 & 1.739 & 26.55 & $23-34$ & 9.32 & $* *$ \\
GFR & 12.091 & 10.52 & 15.76 & 14.3 & $10.07-18.98$ & 13.94 & $* *$ \\
PHT & 41.854 & 40.115 & 4.765 & 91.83 & $80-98$ & 4.07 & $* *$ \\
$\mathrm{CHL}_{\mathrm{A}}$ & 19.984 & 18.75 & 1.234 & 49.51 & $43.5-54.5$ & 5.22 & $* *$ \\
$\mathrm{CT}_{\text {vg }}\left({ }^{\circ} \mathrm{C}\right)$ & 0.585 & 0.312 & 0.273 & 21.03 & $19.9-22.5$ & 2.14 & $* *$ \\
$\mathrm{CT}_{\text {anth }}\left({ }^{\circ} \mathrm{C}\right)$ & 0.514 & 0.236 & 0.278 & 22.08 & $21.1-23.5$ & 1.89 & $* *$ \\
$\mathrm{CT}_{\mathrm{g}}\left({ }^{\circ} \mathrm{C}\right)$ & 0.786 & 0.463 & 0.323 & 23.75 & $21.5-24.9$ & 2.15 & $* *$ \\
Splet/spk. & 3.946 & 3.458 & 0.488 & 16.02 & $13.9-18.4$ & 7.17 & $* *$ \\
Gr./spk. & 46.76 & 31.88 & 14.872 & 50.74 & $40.7-57.9$ & 7.78 & $* *$ \\
TGW & 32.652 & 25.727 & 6.925 & 37.21 & $30.5-45.9$ & 8.86 & $* *$ \\
Grain yield & 815481 & 709547 & 105934 & 3810.14 & $2552-4998$ & 13.68 & $* *$ \\
$(\mathrm{~kg} / \mathrm{ha})$ & & & & & & & \\
\hline
\end{tabular}

** Significant at $1 \%$ level of probability

DTH= Days to heading, DTA= Days to anthesis, DPM=Days to physiological maturity (days); GFD $=$ Grain filling duration, GFR $=$ Grain filling rate, PHT= Plant height $(\mathrm{cm})$, $\mathrm{CHL}_{\mathrm{A}}=$ Chlorophyll content at anthesisstage (SPAD unit), $\mathrm{CT}_{\mathrm{vg}}=$ Canopy temperature at vegetative stage $\left({ }^{\circ} \mathrm{C}\right) ; \mathrm{CT}_{\text {anth }}=$ Canopy temperature at anthesis stage $\left({ }^{\circ} \mathrm{C}\right) ; \mathrm{CT}_{\mathrm{gf}}=\mathrm{Canopy}$ temperature at grain filling stage $\left({ }^{\circ} \mathrm{C}\right)$; Splet/spk.= Spikelets per spike, Gr./spk.= Grains per spike, $\mathrm{TGW}=$ Thousand grain weight, $\mathrm{MS}_{\mathrm{P}}=$ Mean sum of squares due to phenotype, $\mathrm{MS}_{\mathrm{G}}=$ Mean sum of squares due to genotype; MSE= Mean sum of squares due to error.

Days to heading showed significant negative correlation with grain yield $\mathrm{kg} \mathrm{ha}^{-1}$ at genotypic and phenotypic level $\left(\mathrm{r}_{\mathrm{g}}=-0.402 * *\right.$ and $\left.\mathrm{r}_{\mathrm{p}}=-0.381 * *\right)$. This trait had significant negative correlation with grain filling duration $\left(\mathrm{r}_{\mathrm{g}}=-0.823 * *\right.$ and $\mathrm{r}_{\mathrm{p}}=-$ $0.747 * *)$, and canopy temperature at vegetative stage $\left(r_{g}=-0.691\right.$ and $\left.r_{p}=-0.318\right)$ (Table 3). Barma et al. (1990) mentioned that the longer the vegetative period the shorter the grain-filling period. This trait had strong positive association with days to anthesis $\left(r_{g}=0.996^{* *}\right.$ and $\left.r_{p}=0.991^{* *}\right)$ and days to maturity $\left(r_{g}=0.808^{* *}\right.$ and $\left.r_{p}=0.725^{* *}\right)$ at genotypic and phenotypic level. Burio et al. (2004) found negative correlation with days to heading and grain yield.

Plant height showed significant positive association with grain filling rate $\left(r_{\mathrm{g}}=0.393^{*}\right)$, TGW $\left(\mathrm{r}_{\mathrm{g}}=0.285^{*}\right)$, and grain yield $\left(\mathrm{r}_{\mathrm{g}}=0.355^{*}\right)$ at genotypic level (Table 3). Several investigators found plant height to be correlated significantly and positively with grain yield (Hassan et al. 1996; Khan and Bejwa, 1999). But Tila et al., (2005) reported that plant height was negatively correlated with harvest index and grain yield both at genotypic and phenotypic levels. 


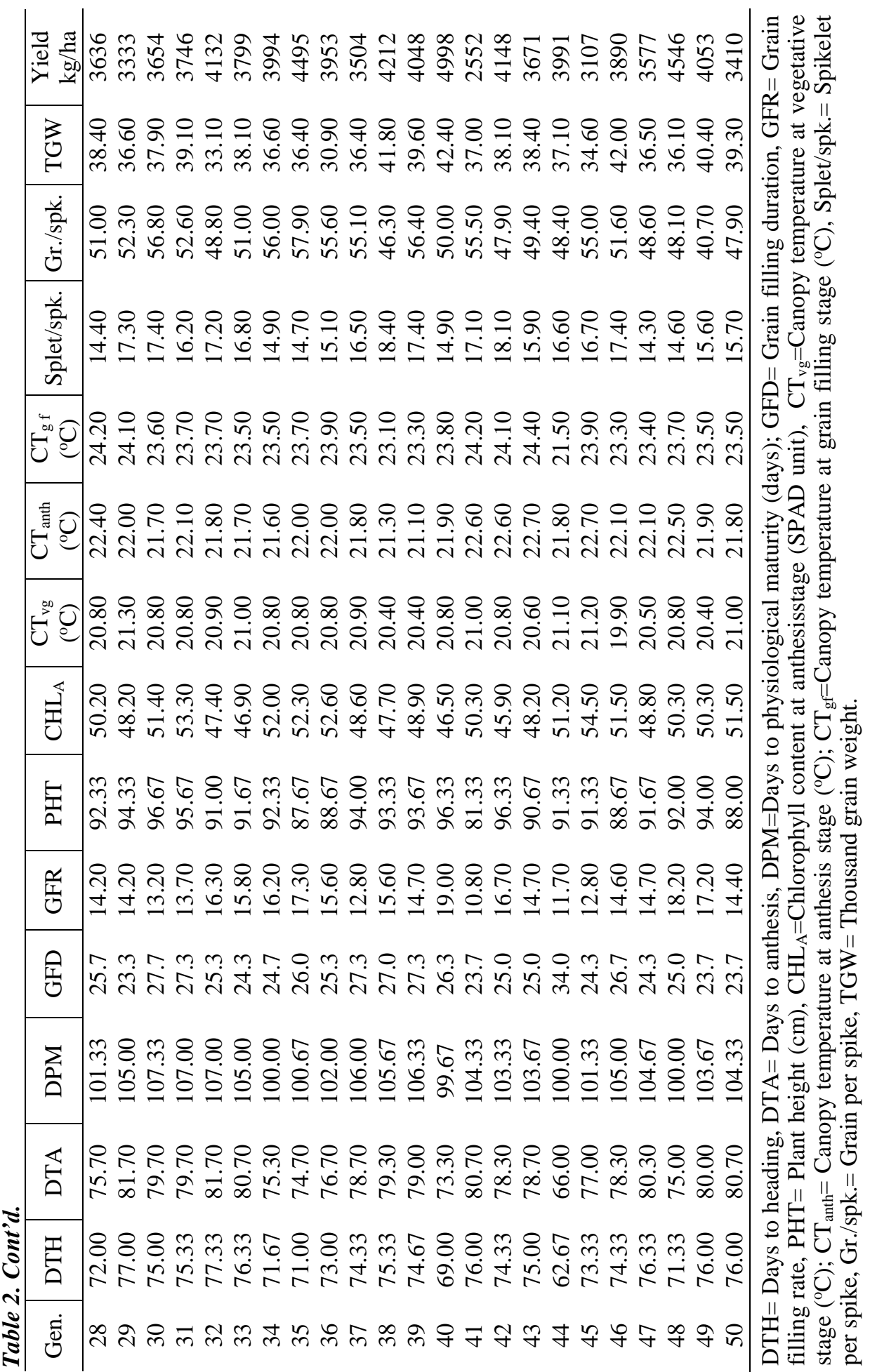


Days to anthesis showed significant negative correlation with GFD $\left(\mathrm{r}_{\mathrm{g}}=-0.791 * *\right.$ and $\left.r_{p}=-0.719^{* *}\right)$ and grain yield $\mathrm{kg} \mathrm{ha}^{-1}\left(\mathrm{r}_{\mathrm{g}}=-0.432 * *\right.$ and $\left.\mathrm{r}_{\mathrm{p}}=-0.401 * *\right)$ at genotypic and phenotypic level. This trait had significant negative correlation with canopy temperature at vegetative stage $\left(r_{\mathrm{g}}=-0.659 * *\right.$ and $\left.\mathrm{r}_{\mathrm{p}}=-0.301 *\right)$ (Table 3). Barma et al. (1990) mentioned that the longer the vegetative period the shorter the grain-filling period. Days to anthesis had strong positive association with days to maturity $\left(r_{\mathrm{g}}=0.844^{* *}\right.$ and $\left.\mathrm{r}_{\mathrm{p}}=0.766^{* *}\right)$ at genotypic and phenotypic level. All these associations indicate that long vegetative growth coupled with delayed anthesis was detrimental trait in late sown condition. Longer vegetative growth period only could increase seed setting to some extent but the ultimate result was negative. Delayed anthesis exposes the crop to sharply rising high temperature which cut the grain filling period causing inadequate grain filling. Burio et al., (2004) observed negative correlation between days to anthesis and grain yield. Amin et al., (1992) reported significant negative correlation between days to anthesis and grain filling period.

Days to physiological maturity showed significant negative correlation with grain yield $\mathrm{kg} \mathrm{ha}^{-1}$ at genotypic and phenotypic level $\left(\mathrm{r}_{\mathrm{g}}=-0.439 * *\right.$ and $\left.\mathrm{r}_{\mathrm{p}}=-0.325^{* *}\right)$. It showed negative correlation with all the characters except spikelet per spike $\left(r_{g}=-0.238\right.$ and $\left.r_{p}=-0.205\right)$ and grain per spike $\left(r_{g}=-0.051\right.$ and $\left.r_{p}=-0.004\right)$ both at genotypic and phenotypic levels (Table 3 ). This association indicates that late maturing genotypes had longer duration of grain filling. Rahman (2009) reported significant positive correlation of grain filling period with maturity period. Sangam (1994) reported that this trait exhibited negative association with grain yield but Jadhav (1994) reported positive and significant association.

Grain filling duration (GFD) showed significant positive correlation at genotypic level and insignificant positive correlation at phenotypic level $\left(\mathrm{r}_{\mathrm{g}}=0.649 * *\right.$ and $\left.r_{p}=0.255\right)$ with Canopy temperature at vegetative stage (Table 3). But canopy temperature at grain filling stage $\left(r_{g}=-0.289^{*}\right.$ and $\left.r_{p}=-0.179\right)$ showed significant negative correlation at genotypic level and insignificant negative correlation at phenotypic level and GFR $\left(r_{\mathrm{g}}=-0.356^{*}\right.$ and $\left.\mathrm{r}_{\mathrm{p}}=0.326^{*}\right)$ showed significant negative correlation at genotypic and phenotypic level (Table 3). Rahman (2009) observed significant positive correlation for GFD with grain yield and insignificant positive correlation with biomass. He also reported GFD was negatively correlated with grain filling rate.

Grain filling rate (GFR) $\left(\mathrm{g} \mathrm{d}^{-1} \mathrm{~m}^{-2}\right)$ showed very strong positive correlation with grain yield $\left(r_{g}=0.682^{* *}\right.$ and $\left.r_{p}=0.995^{* *}\right)$. The result revealed that faster grain filling rate increased the grain yield significantly (Table 3 ). There was a significant negative association of this trait with canopy temperature at vegetative stage $\left(r_{\mathrm{g}}=-0.446^{* *}\right.$ and $\left.\mathrm{r}_{\mathrm{p}}=-0.213\right)$ and canopy temperature at anthesis stage $\left(\mathrm{r}_{\mathrm{g}}=\right.$ $-0.311^{*}$ and $\left.r_{p}=-0.148\right)$ at genotypic level and insignificant negative association at phenotypic level. Barma (2005) and Rahman (2009) reported strong and positive correlation of grain filling rate with grain yield. 
Chlorophyll content of flag leaf at anthesis stage $\left(\mathrm{CHL}_{\mathrm{A}}\right)$ showed insignificant positive correlation with grain yield $\left(r_{g}=0.159\right.$ and $\left.r_{p}=0.123\right)$, TGW $\left(r_{g}=0.153\right.$ and $\left.r_{p}=0.124\right)$, and grain per spike $\left(r_{g}=0.234\right.$ and $\left.r_{p}=0.195\right)$ both at genotypic and phenotypic level (Table 3). Hede et al., (1999) found highly significant correlations between leaf chlorophyll content and 1000-grain weight. Rahman (1996) reported that flag leaf chlorophyll content measured at 2nd and 3rd week after anthesis showed significant and positive correlation with grain yield.

Canopy temperature at vegetative stage $\left(\mathrm{CT}_{\mathrm{vg}}\right)$ had significant negative correlation with TGW $\left(r_{\mathrm{g}}=-0.175\right.$ and $\left.\mathrm{r}_{\mathrm{p}}=-0.288^{*}\right)$ at phenotypic level and insignificant at genotypic level (Table 3). $\mathrm{CT}_{\mathrm{vg}}$ showed significant positive correlation with $\mathrm{CT}_{\text {anth }}\left(\mathrm{r}_{\mathrm{g}}=0.425^{* *}\right.$ and $\left.\mathrm{r}_{\mathrm{p}}=0.428^{* *}\right)$ at genotypic and phenotypic level but $\mathrm{CT}_{\mathrm{gf}}\left(\mathrm{r}_{\mathrm{g}}=0.357^{*}\right.$ and $\left.\mathrm{r}_{\mathrm{p}}=0.237\right)$ showed significant positive correlation with this trait at genotypic and insignificant positive correlation at phenotypic level. Rees et al., (1993) found canopy temperature depression (CTD) and photosynthetic activity to be positively correlated with grain yield. Rahman et al., (1997) observed that high yielding genotypes possess significantly low canopy temperature and medium chlorophyll content. Balota et al. (2007) also observed significant correlation coefficients of CTD at three developmental stages i.e. preheading, heading and post-anthesis stages with grain yield. CIMMYT began CTD measurements on different irrigated experiments in Northwest Mexico and it was found that phenotypic correlations of CTD with grain yield were occasionally positive (Reynolds et al., 1994; Fischer et al., 1998). They also reported that CTD has been used as a selection criterion for tolerance to drought and high temperature stress in wheat breeding and the used breeding method generally comes by mass selection in early generations like $\mathrm{F}_{3}$.

Canopy temperature at anthesis stage $\left(\mathrm{CT}_{\text {anth. }}\right)$ had significantly negative correlation with grain yield $\left(r_{g}=-0.298 *\right.$ and $\left.r_{p}=-0.147\right)$ and grain per spike $\left(r_{g}=-\right.$ $0.284 *$ and $\left.r_{p}=-0.092\right)$ at genotypic level but insignificant at phenotypic level (Table 3).

Canopy temperature at grain filling stage $\left(\mathrm{CT}_{\mathrm{gf}}\right)$ had significant negative correlation with spikelet per spike $\left(r_{g}=-0.283^{*}\right.$ and $\left.r_{p}=-0.055\right)$ and grain per spike $\left(r_{\mathrm{g}}=-0.285^{*}\right.$ and $\left.\mathrm{r}_{\mathrm{p}}=-0.059\right)$ at genotypic and insignificant at phenotypic level (Table 3). Rahman (2009) reported strong and negative correlation of $\mathrm{CT}_{\mathrm{gf}}$ with grain yield.

Spikelets per spike had significant positive correlation with TGW $\left(\mathrm{r}_{\mathrm{g}}=0.331^{*}\right.$ and $r_{p}=0.223$ ) at genotypic level and insignificant positive correlation at phenotypic level (Table 3). The insignificant negative correlation was noticed between grains spike ${ }^{-1}$ and grain yield $\left(r_{g}=-0.029\right.$ and $\left.r_{p}=0.013\right)$ at genotypic level while it was positive and insignificant at phenotypic level. Singh \& Sharma (1999) observed negative correlation of grains per spike and grain yield but several authors (Gautam et al., 2002; Bergalie et al., 2001; Shukla et al.,2005) 
had reported that significant and positive correlation of grains per spike and grain yield. However, negative insignificant correlation between grains spike ${ }^{-1}$ and TGW $\left(r_{g}=-0.204\right.$ and $\left.r_{p}=-0.034\right)$ was obtained in the tested experiment. The negative correlation between grains spike ${ }^{-1}$ and TGW indicates a competitive demand of both sinks (grain number and size) for photosynthates from a common source, which expressed through a compensating balance between two traits under stress condition.

Thousand grains weight (TGW) (g) showed insignificant positive correlation with grain yield $\left(r_{\mathrm{g}}=0.091\right.$ and $\left.r_{\mathrm{p}}=0.155\right)$ both at genotypic and phenotypic level (Table 3). Guttieri et al., (2001) observed that decrease in grain weight of each spike due to drought during grain filling period. Wardlaw et al., (1989) suggested individual grain weight as to be the most sensitive yield component to high temperature. Several authors (Singh et al., 1997; Narwal et al., 1999; Nayeem et al., 2003; Jat et al., 2003; Zecevic et al., 2004) had reported significant and positive correlation of 1000-grain weight with grain yield.

\section{Path coefficient analysis}

Association of characters determined by correlation co-efficient may not provide an exact picture of the relative importance of direct and indirect influence of each of yield components on seed yield. In order to find out a clear picture of the interrelationship between seed yield and other yield attributes, direct and indirect effects were worked out using path analysis at phenotypic level which also measured the relative importance of each component. Seed yield was considered as a resultant (dependent) variable and others were causal (independent) variables. Estimates of direct and indirect effects of path coefficient analysis are presented in Table 4. Residual effects which have influenced yield to a small extent have been denoted as " $\mathrm{R}$ " The results are discussed character wise as follows:

Days to heading (DTH) had high negative direct effect on grain yield ha-1 ($0.9562)$. It contributed high negative indirect effect on yield via days to anthesis (-10.6496), spikelets spike ${ }^{-1}(-0.0692)$, grain filling rate (-0.0332), and canopy temperature at anthesis stage (0.0145). Days to heading however showed positive indirect effect on grain yield through days to maturity (5.4769), grain filling period (4.2476), canopy temperature at vegetative stage (1.4034), canopy temperature at grain filling stage (0.0973), plant height (0.0451), grain per spike (0.0433), chlorophyll content at anthesis stage (0.0068), and thousand grain weight (0.0003). Which ultimately resulted the total significant negative correlation with grain yield $(-0.4020 * *)$ (Table 4$)$.

Plant height $(\mathrm{cm})$ showed positive direct effect on yield (0.8232). It also showed positive indirect effect via grain filling period (0.3745), canopy temperature at grain filling stage (0.0237), canopy temperature at anthesis stage $(0.0080)$, and 
thousand grain weight (0.0009). The highest indirect negative effect on yield through days to anthesis (-0.2809), days to maturity $(-0.2117)$, grain filling rate ($0.1341)$, spikelets per spike $(-0.0858)$ canopy temperature at vegetative stage $(-0.0629)$, days to heading $(-0.0524)$, chlorophyll content at anthesis stage ($0.0259)$, and grain per spike $(-0.0219)$. Which led to significant positive correlation with grain yield at genotypic level $\left(0.3548^{*}\right)$ (Table 4$)$. Chaturvedi et al. (1995) and Halloli (1997) reported positive direct effect on grain yield. But Ehdaie and Waines (1989) found plant height to be negatively correlated with grain yield at genotypic level.

Days to anthesis (DTA) had very high negative direct effect on grain yield (10.694). It contributed high negative indirect effect on yield via days to heading $(-0.952)$, spikelets per spike $(-0.070)$, and grain filling rate $(-0.016)$. Days to anthesis however showed positive indirect effect on grain yield through days to maturity (5.7182), grain filling period (4.0811), canopy temperature at vegetative stage (1.3389), canopy temperature at grain filling stage (0.0799), grain per spike (0.0341), plant height (0.0216), canopy temperature at anthesis stage (0.0166), chlorophyll content at anthesis stage (0.0107), and thousand grain weight (0.0003). Which ultimately resulted the total significant negative correlation with grain yield $(-0.4319 * *)$ (Table 4$)$. Burio et al., (2004) found significant negative correlation between days to anthesis and grain yield.

Days to physiological maturity (DPM) showed high positive direct effect on grain yield (6.7791). The indirect effect via grain filling period (1.747), grain filling rate (0.0817), chlorophyll content at anthesis stage (0.0311), canopy temperature at vegetative stage (0.9136), canopy temperature at anthesis stage (0.0218), and thousand grain weight $(0.0001)$ was positive. There was a strong negative indirect effect through days to anthesis (-9.0206) on yield followed by days to heading $(-0.7725)$. The indirect effects of other traits on yield were also negative. It resulted ultimately the total genotypic correlation significantly negative with yield $(-0.4393 * *)$ (Table 4$)$.

Grain filling duration (GFD) showed high negative (-5.1588) direct effect on yield. The indirect effect via plant height $(-0.0598)$, days to physiological maturity (-2.2957), canopy temperature at vegetative stage-1.3179, canopy temperature at anthesis stage (-0.0038), canopy temperature at grain filling stage $(-0.1828)$, spikelets per spike $(-0.0232)$, grain per spike $(-0.0859)$, and thousand grain weight $(-0.0004)$ was negative. There was a strong positive indirect effect through days to anthesis (8.46) on yield followed by days to heading (0.7873). The indirect effects of other traits on yield were also positive. It resulted ultimately the total genotypic correlation positive with yield (0.2574) (Table 4). Gashaw et al., (2007) reported that grain filling period had negative direct effect $(-0.52)$ on yield. 


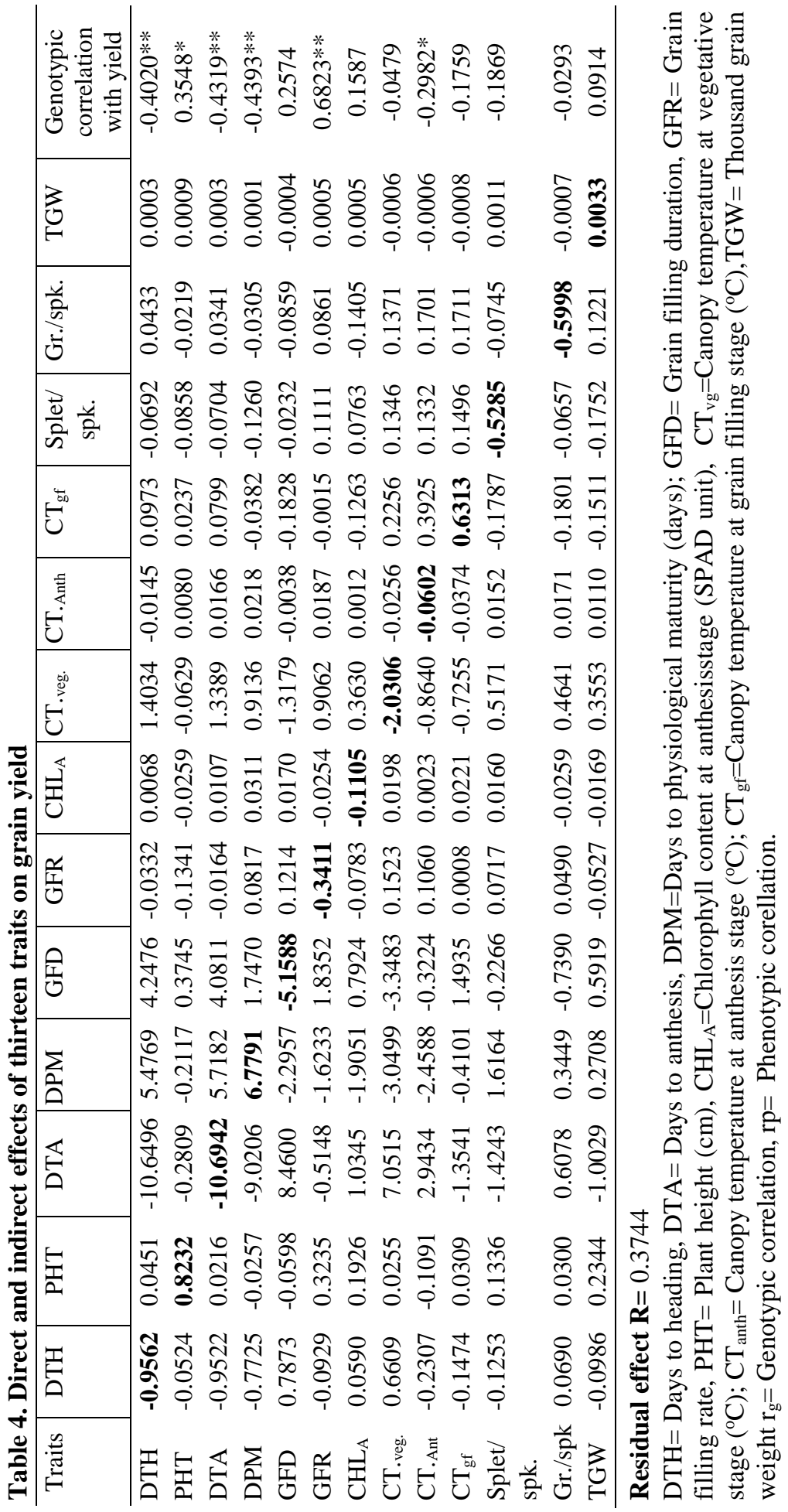


The direct effect of grain filling rate (GFR) $\left[\mathrm{g} \mathrm{d}^{-1} \mathrm{~m}^{-2}\right]$ was negative $(-0.3411)$ on grain yield although it showed highly significant positive correlation with yield (0.6823) (Table 4). The indirect effect through days to maturity $(-1.6233)$ and days to anthesis $(-0.5148)$ on yield was very high and negative. But indirect effect through grain filling rate and canopy temperature at vegetative stage on yield (0.9062) was positive and high. The indirect effect of grain filling rate via all other characters on yield was also positive. Thus, negative direct effect was counter balanced by high positive indirect effects and total correlation coefficient was significantly positive (0.6823) between grain filling rate and grain yield. So, indirect causal factors should be considered simultaneously for selection. Barma (2006) reported significant positive correlation of grain filling rate with grain yield.

Chlorophyll (CHL) content of flag leaf at anthesis stage $\left(\mathrm{CHL}_{\mathrm{A}}\right)$ had negative direct effect (-0.1105) on yield. But indirect effect on yield via days to maturity ($1.9051)$ was high followed by grains per spike (-0.1405), and canopy temperature at grain filling stage $(-0.1263)$. The indirect effect via grain filling rate $(-0.0783)$ was negative but low in magnitude. But indirect effect through days to anthesis (1.0345), grain filling duration (0.7924) and plant height (0.1926) on yield was positive and high. The indirect effect of chlorophyll (CHL) content of flag leaf at anthesis stage $\left(\mathrm{CHL}_{\mathrm{A}}\right)$ via all other characters on yield was also positive (Table 4). This resulted positive genotypic correlation of chlorophyll content $(0.1587)$ with yield. Barma (2006) found significant genotypic correlation of chlorophyll content with grain yield.

Canopy temperature at vegetative stage (CTveg) had highly negative direct effect (-2.0306) on yield. But indirect effect on yield via grain filling period ($3.3483)$ was high followed by days to maturity $(-3.0499)$. The indirect effect via canopy temperature at anthesis stage (-0.0256) and thousand grain weight (0.0006 ) was negative but low in magnitude. But indirect effect through days to anthesis (7.0515) and days to heading (0.6609) on yield was positive and high. The indirect effect of canopy temperature at vegetative stage via all other characters on yield was also positive. This resulted negative genotypic correlation of canopy temperature at vegetative stage $(-0.0479)$ with yield (Table 4).

Canopy temperature at anthesis stage $\left(\mathrm{CT}_{\text {anth. }}\right)$ had negative direct effect ($0.0602)$ on yield. But indirect effect on yield via days to maturity $(-2.4588)$ was high followed by canopy temperature at vegetative stage $(-0.8640)$, grain filling period (-0.3224), and days to heading $(-0.2307)$. The indirect effect via plant height (-0.1091) and thousand grain weight $(-0.0006)$ was negative but low in magnitude. But indirect effect through days to anthesis (2.9434) on yield was positive and high. The indirect effect of canopy temperature at anthesis stage via all other characters on yield was also positive. This resulted significant negative genotypic correlation of canopy temperature at anthesis stage (0.2982 ) with yield (Table 4). 
Canopy temperature at grain filling stage $\left({ }^{0} \mathrm{C}\right)$ had positive direct effect $(0.6313)$ on yield. But indirect effect on yield via grain filling period (1.4935) was high followed by grains per spike (0.1711) and spikelets per spike (0.1496). The indirect effect via plant height (0.0309) and grain filling rate $(0.0008)$ was positive but low in magnitude. But indirect effect through days to anthesis (1.3541) on yield was negative and high. The indirect effect of canopy temperature at grain filling stage via all other characters on yield was also negative. This resulted negative genotypic correlation of canopy temperature at grain filling stage $(-0.1759)$ with yield (Table 4$)$.

The direct effect of spikelets per spike on yield was negative (-0.5285) but moderate in magnitude (Table 4). The indirect effect via days to anthesis (1.4243) was high followed by grain filling duration (-0.2266), canopy temperature at grain filling stage $(-0.1787)$, and days to heading $(-0.1253)$. The indirect effect via grains per spike (-0.0745) was negative but low in magnitude. There was a strong positive and indirect effect through days to maturity (1.6164) on yield followed by canopy temperature at vegetative stage (0.5171) and plant height (0.1336). The indirect effects of other traits on yield were also positive. This resulted negative genotypic correlation of spikelets per spike (-0.1869) with yield

Grains spike ${ }^{-1}$ had direct negative effect on yield (-0.5998). This trait had maximum indirect negative effect on yield via grain filling period $(-0.7390)$ followed by canopy temperature at grain filling stage $(-0.1801)$, spikelets per spike (-0.0657), chlorophyll content of flag leaf at anthesis stage (-0.0259), and TGW (-0.0007). A number of positive indirect effects on yield were observed for this trait via days to anthesis (0.6078), canopy temperature at vegetative stage $(0.4641)$, days to maturity (0.3449), days to heading $(0.0690)$, grain filling rate $(0.0490)$, plant height $(0.0300)$, and canopy temperature at anthesis stage (0.0171). All these ultimately led to negative correlation with yield (-0.0293) at genotypic level (Table 4). But Subhani et al., (2000) observed highly positive association between grains spike ${ }^{-1}$ and grain yield in bread wheat.

Thousand grains weight (TGW) [g] showed direct positive effect on grain yield (0.0033) but low. This trait had maximum indirect positive effect on yield via grain filling period (0.5919) followed by canopy temperature at vegetative stage (0.3553), plant height (0.2344), days to maturity $(0.2708)$, grains per spike (0.1221), and canopy temperature at anthesis stage (0.0110). There was a strong negative and indirect effect through days to anthesis (-1.0029) on yield followed by spikelets per spike $(-0.1752)$ and canopy temperature at grain filling stage $(-0.1511)$. The indirect effects of other traits on yield were also negative. This resulted positive genotypic correlation of thousand grains weight (g) with yield (0.0914) (Table 4). Ibrahim (1994) and Deshmukh et al. (1990) observed in direct positive effect of thousand grains weight $(\mathrm{g})$ on grain yield in bread wheat and durum wheat respectively. The residual effect $(0.3744)$ indicated that the character under study contributed $62.56 \%$ of the yield. It is 
suggested that there are some other characters those contributed $37.44 \%$ to the grain yield $\mathrm{m}^{-2}$ (Table 4). Considering analytical findings of correlation coefficient, path co-efficient analysis and field performance, the genotypes $\mathrm{G} \mathrm{3,} \mathrm{G}$ 10, G 11, G 12, G13, G 21, G 29, G 35, G 38, G 40, G 46 and G 48 were found suitable for future breeding programme.

\section{References}

Amin, M. R., N. C. D. Barma and M. A. Razzaque. 1992. Variability, Heritability, Genetic Advance and Correlation Study in some Quantitative Characters in Durum Wheat. Rachis 11 (1 \& 2):30-32.

Balota, M., W.A. Payne, S.R. Evett and M.D. Lazar. 2007. Canopy temperature depression sampling to assess grain yield and genotypic differentiation in winter wheat. Crop-Science. 47(4): 1518-1529.

Barma, N.C.D. 2005. Genetic study of morpho-physiological traits related to heat tolerance in spring wheat. Ph.D. Thesis, Dept. of Genetics and Plant Breeding, BAU, Mymensingh.

Barma, N.C.D., D.B. Pandit, A. Babar, M.A.H.S. Jahan and M.A. Razzaque. 2002. Biomass as a selection parameter for improving grain yield in wheat (T. aestivum L.). Bangladesh J. of Agril. Sci. 29(1):91-94.

Barma, N. C. D., S. H. Khan, M. A. K. Mian and A. Islam. 1990. Variability and Interrelationships of eight Quantitative Characters in Bread Wheat (Triticum aestivum L.). Bangladesh J. Plant Breed. Genet. 3 (1 \& 2): 71-75.

Behl, R.K., B.D. Chowdhury, R.P. Shingh and D.P. Shingh. 1992. Morphophysiological determinants of oil yield in Brassica juncea under dry land conditions. Indian J. Genet. Pl. Breed. 52 (3): PP. 280- 284.

Bergalie, S., M. Billore, A.S. Holkar, K.N. Ruwali, S.V.S. Prasad and B. Mridulla. 2001. Genetic variability, diversity and association of quantitative traits with grain yield in bread wheat (Triticum aestivum L.). Madras Agric. J. 88(7-9): 457-461.

Burio, U. A., F. C. Oad and S. K. Agha. 2004. Correlation coefficient (r) values of growth and yield components of wheat under different nitrogen levels and placements. Asian Journal of Plant Sciences 3 (3): 372-374.

Burton, G. W. 1952. Quantitative inheritance in grasses. Proc. sixth Int. Grassland Cong. 1: 277-283.

Chaturvedi, B. K. and R. R. Gupta. 1995. Selection parameters for some grain and quality attributes in spring wheat (Triticum aestivum L.). Agric. Sci. Digest. 15(4): 186-190, Karnal, India.

Clarke, G.M. 1973. Statistics and Experimental Design. Edward Arnold., London.

Deshmukh, P.W., S.B. Atale, P.W. Korgade and D.C.Vitkre. 1990. Evaluation of some yield contributing characters under rainfed and irrigated conditions in durum wheat. Ann Pl Physiol. 4: 80-85.

Dewey, D.R. and K.H. Lu. 1959. A Correlation and path-coefficient analysis of components of crested wheatgrass seed production. Agron. J. 51: 515-518.

Ehdaie, B. and J. G. Waines. 1989. Genetic variation, heritability and path-analysis in landraces of bread wheat from southwestern Iran. Euphytica 41(3): 183-190. 
Fischer, R.A., D. Rees, K.D. Sayre, Lu ZM, A.G. Condon and A. Larque Saavedra .1998. Wheat yield progress associated with higher stomatal conductance and photosynthetic rate, and cooler canopies. Crop Sci. 38: 1467-1475.

Gashaw, A., H. Mohammedi and H. Singh. 2007. Selection Criterion for Improved Grain Yield in Ethiopian Durum Wheat Genotypes. African Crop Science Journal 15 (1): $25-31$

Gautam, R.K. and G. S. Sethi. 2002. Character association in Secale cereale L. introgressed bread wheat under irrigated and water stress conditions. Indian J. Genet. and P1.Bree. 62(1): 69-70.

Guttieri, M. J., J. C. Stark, K. Obrien and E. Souza . 2001. Relative sensitivity of spring wheat grain yield and quality parameters to moisture deficit. Crop Sci. 41: 327-335

Halloli, 1997. Characters association and adaptation in advanced generation of tetraploid wheat. M.Sc. (Agri.) Thesis, University of Agricultural Sciences, Dharwad.

Hassan, A. M., M. S. Abdel-Sabour, A. A. Abdel-Shafi, H. S. Sherif and A.A. Hamada 1996. Genetic analysis of diallel crosses in bread wheat under different environmental conditions in Egypt $1 \mathrm{~F} 1$ and parents. Indian .J .Gen. and Pl. Breed. 56(1): 34-38.

Hede, A.R., B. Skovmand, M.P. Reynolds, J. Crossa, A.L. Vilhelmsen and O. Stolen.1999. Evaluating genetic diversity for heat tolerance traits in Mexican wheat landraces.Genetic Resources and Crop Evolution. 46(1): 3745.

Jadhav, A.S. 1994. Correlation studies in wheat. Madras Agricultural J. 81(5): 274-275.

Jat, B. L. and L. L. Dhakar. 2003. Correlation and regression studies in wheat. Envt and Eco. 21 (1): 34-36.

Johnson, H. W., H. F. Robinson and R. E. Comstock. 1955. Estimation of genetic and environmental variability in soybean. Agronomy Journal 47: 314-318.

Khan, N. and H.A. Bejwa. 1999. Variability and correlation between metric traits in wheat. J. Agric Res. 31(2):131-137.

Miller, P.J., J.C. Williams. H.F. Robinson and R.E. Comstock. 1958. Estimation of genotypic and environmental variances and covariances in upland cotton and their implication in selection. Agron. J. 50: 126-131.

Narwal, N.K., P.K. Verma and M.S. Narwal. 1999. Genetic variability, correlation and path coefficient analysis in bread wheat in two climatic zones of Haryana. Agric SciDig, Karnal, 19(2): 73-76.

Nayeem, K. A., K. S. Baig and N.S. Karad. 2003. Genetic variability and character association studies for export quality parameters in T. durum wheat. J Res. Angrau. 30(4): 5-10.

Panse, V. G. 1957. Genetics of quantitative characters in relation to plant breeding. Indian J. Genet. 17:318-328

Rahman, M.M. 2009. Genetic variability and genotypes-environment interaction in wheat. M.S. Thesis, Bangabandhu Sheikh Mujibur Rahman Agricultural University, Gazipur.

Rahman, M.M., A.B.S. Hossain, N.K. Saba and P.K. Malaker. 1997. Selection of morpho-physiological traits for heat tolerance in wheat. Bangladesh J. Sci. Ind. Res. 32(2): 161-165 
Rahman, M.M.1996. Screening technique for canopy temperature and leaf chlorophyll content in wheat. Bangladesh J. Pl. Genet. 9 (1 \& 2): 1-6.

Rees, D., K. Sayre, E. Acevedo, T.N. Sanchez, Z. Lu, E. Zeiger and L. Limon. 1993.Canopy temperatures of wheat: Relationship with yield and potential as a technique for early generation selection. Wheat Special Report 10, Mexico, D. F., CIMMYT.

Reynolds, M. P., M. Balota, M. I. B. Delgado, I. Amani and R. A. Fischer. 1994. Pyhsiological and morphological traits associated with spring wheat yield under hot, irrigated conditions. Aust. J. Plant Physiol. 21: 717-730

Sangam, V. S. 1994. Phenotypic stability, heat tolerance, characters association and path analysis in wheat genotypes under heat stress environment. M.Sc.(Agri.)Thesis, University of Agricultural Sciences, Dharwad.

Shukla, R.S., S.K. Rao and C.B. Singh. 2005. Character association and path analysis in bread wheat under rainfed and partially irrigated condition. JNKVV Res. J. 39: 2025.

Singh, G.C.P. and N. N. Sharma . 1999. Correlation, regression and path analysis studies in wheat varieties. Indian J. Agron. 25: 225-229.

Singh, I., A.S. Radhu and Y.Tindal. 1997. Harevst index a better selection criterion for yield improvement in bread wheat. Haryana Agril. Univ. J. Res. 7(1): 27-30.

Singh, R.K. and B.D. Chowdhury. 1985. Biometrical methods in quantitative genetic analysis. Kalyani Publishers, New Delhi, India. P. 56.

Tila, M., H. Sajjad, J. Qureshi, A. J. Khan and Z. Roshan. 2005. Correlation and path analysis in candidate bread wheat (Triticum aestivum L.) lines evaluated in microplot test trial. Pakistan Journal of Scientific and Industrial Research 48 (4): 284-288.

Turkey, J.W. 1954. causation of segregation and path analysis of casual path biometrics. 15: 236- 258.

Wardlaw, I.F., I. Sofield and P.M. Cartwright. 1989. Factors limiting the rate of dry matter accumulation in grain of wheat grown at high temperature. Aust. J. Plant Physiol. 7: 387-400.

Wright, S. 1959. Theory of path co-efficient. Genetics 8: 239- 255.

Zecevic, V., D. Knezevic and D. Micnovic. 2004. Genetic correlation and path coefficient analysis of yield and quality components in wheat (Triticum aestivum L.). GENETIKA. 36 (1): 13-21. 